\title{
Learning to Take Scripture Seriously
}

\author{
Evan D. Garner
}

\begin{abstract}
This paper is mainly the product of an international conference on sexuality and scripture that was held in Limuru, Kenya, during the summer of 2013. For almost two-thousand years, Christians have held different views on the role and authority of scripture in the Church. Those differences were made manifest by the participants in this conference. Largely because of their diverse cultural backgrounds, leaders from different parts of the global Christian community continue to use the Bible in the debates over human sexuality in remarkably different ways. This paper identifies the Contextual Bible Study method as a promising hermeneutical tool for finding agreement in the interpretation of scripture among individuals from such diverse backgrounds and from competing theological positions. After reviewing the Contextual Bible Study method and its applicability to the issue of human sexuality, the paper suggests the benefits of leaving behind familiar arguments over those passages of scripture most often cited in these debates in favour of a robust discussion of yet largely unexplored theological arguments.
\end{abstract}

\section{Introduction}

In the summer of 2013, a group of forty-three Anglicans from Africa and North America joined a few ecumenical partners in Limuru, Kenya, for a three-day conference on human sexuality and scripture. ${ }^{1}$ The participants were invited by the Chicago Consultation, an organization dedicated to the full inclusion of lesbian, gay, bisexual, and transgendered (LGBT) individuals in the life of the Church. Most of the participants were either ordained church leaders-bishops, deans of cathedrals, or clergy in charge of large congregations-or theologians at seminaries or secular universities. Some were representatives of the Chicago Consultation who gathered not only to take part but also to assist with the administration of the conference. A few of us, however, were invited because we represent the "movable middle" - a phrase used by members of the Chicago Consultation to describe church leaders who identify primarily with traditional points of view but who seem open to a dialogue about the role of LGBT individuals in the Church.

As a member of that last group, I travelled to Kenya not knowing what I would experience or what I could contribute to the conference. During those three days, we engaged in deep, prolonged bible study. We worshipped and prayed together. We shared stories from our own background experiences and listened to the stories of others. We ate and talked together in casual, informal settings. We dreamt about ways to expand the transatlantic conversation on sexuality and scripture and discussed how each of us would bring that

\footnotetext{
${ }^{1}$ Chicago Consultation. (2013). Consultation in Kenya. Retrieved December 14, 2013, from http://www.chicagoconsultation.org/article/66/in-the-news/consultation-in-kenya.
} 
conversation to his or her own community. Throughout it all, I noted how representatives from radically different cultures and contexts were able to explore in lively, personal, and thorough ways those issues that continue to confound contemporary Christians.

By the time we left, my expectations for the future of the debate on the role of LGBT individuals in the sacramental life of the Church had shifted dramatically. To my surprise, I discovered that there are a considerable number of open and vocal advocates for full inclusion within the African provinces of the Anglican Communion, including a handful of bishops. Yet, despite their remarkable agreement on issues of sexuality, the African and North American Anglicans at the conference revealed how they continue to approach the Bible in radically different ways. Seeing that profound hermeneutical difference among the like-minded people at the conference has led me to believe that the one thing that stands in the way of a constructive conversation on issues of human sexuality is a systemic pattern of limited and inflexible interpretation of scripture undertaken by both sides of the issue, and I believe that the only way the Church will hold itself together is for both conservatives and liberals to learn again how to take scripture seriously.

\section{Hermeneutical divide}

One important aspect of the conference was the full integration of North American and African participants. During plenary sessions, seating around the tables was mixed, and presenters alternated between continents of origin. The break-out groups were carefully balanced so that bible study and reflection were undertaken within a geographically diverse context. As the conference neared its end, however, that practice was intentionally broken to allow each geographically-centred contingent to discuss issues particular to its own identity in order to identify what steps should be taken to ensure the effective continuation of this conversation on sexuality and scripture. In one of these gatherings, a most informative distinction was discovered.

In the North American regional meeting, a bishop from the Episcopal Church (USA) shared his frustrations that the only theological warrant being discussed during the conference was scripture. Referring to our shared Anglican heritage, he questioned why tradition and reason, the other legs of Richard Hooker's supposed "three-legged stool," largely had been ignored. His comments gave great insight into the separation that exists between the African and North American contexts within the Anglican Communion and, in a related though not necessarily overlapping way, the divide between the so-called conservative and liberal wings of the Church. This bishop spoke from a position of genuine surprise and disappointment. His remarks made it clear that a foundational principle of Anglicanism as he understood it was a balance between scripture, tradition, and reason. The African Anglicans, of course, did not share that understanding (as evidenced by their exclusively Bible-focused contributions to the conference). Their scripture-dominant interpretation of Anglicanism has its roots in the original expression of Hooker, who never wrote of a "three-legged stool," but, instead, wrote, "Be it in matter of the one kind or of the other, what Scripture doth plainly deliver, to 
that the first place both of credit and obedience is due; the next whereunto is whatsoever any man can necessarily conclude by force of reason; after these the voice of the Church succeedeth." ${ }^{2}$

Some of the other North American participants shared frustrations similar to those of the bishop, while others balanced those objections by articulating a broader understanding of Anglicanism. Everyone agreed that the future of issue-specific collaboration between African and North American Anglicans was threatened by the perceived cultural gap between the dominant expressions of Anglicanism in those two contexts. What I learned in the exchange that followed was that my perspective, as a relatively traditional Episcopalian from the region of the United States known as "the Bible Belt," had more in common with that of the African participants than that of many of my North American colleagues. In my culture and context, one dominated by conservative, evangelical, Protestant expressions of Christianity, an appeal to tradition and reason (at the exclusion of scripture) has little persuasive effect. ${ }^{3}$ Similarly, several African church leaders spoke of many impoverished parishioners whose families only owned one book-the Bible. No wonder Anglicans from those two continents (and other similar backgrounds) have struggled to undertake a successful, productive dialogue on scripture!

As I listened to some of the North Americans describe the unfamiliarity of an Anglicanism that traces its roots to the sola scriptura of the Protestant Reformation, I realized why a theological gap exists between the liberals and conservatives within the Episcopal Church and across the Anglican Communion-because neither has figured out how to read and interpret the Bible in the context of the other. Still, though, the work done at that conference was of great value in bridging the gap between Anglicans of different contexts. That outcome suggests that the model of intensive study of scripture undertaken during that three-day conference might enable productive dialogue among theologically divergent leaders within the wider Church.

\section{Texts of terror}

The form of Bible study used during the conference was the Contextual Bible Study model, which has been written about and implemented by Gerald West on several occasions, including as the model for the Bible studies held at Lambeth Conference 2008. ${ }^{4}$ Essentially, this approach to the study of scripture is based on the "See-Judge-Act" process, which

\footnotetext{
${ }^{2}$ Hooker, R. (1888). Of the Laws of Ecclesiastical Polity (Book V, 8:2). In Isaac Walton (Ed.), The Works of that Learned and Judicious Divine Mr. Richard Hooker with an Account of His Life and Death (7th ed.). Oxford: Clarendon Press. Retrieved December 27, 2013, from http://oll.libertyfund.org/title/922/85486.

${ }^{3}$ For a point of cultural reference, consider the 2012 reelection in Alabama of State Supreme Court Chief Justice Roy Moore, who was removed from the same position in 2003 "for refusing to remove a Ten Commandments monument that he installed in the rotunda of the Alabama Judicial Building to acknowledge the sovereignty of God." Alabama Judicial System. (2013). Chief Justice. Retrieved December 27, 2013, from http://judicial.alabama.gov/Bios/rmoore.cfm.

${ }^{4}$ West, G. (2011). Do Two Walk Together? Walking with the Other through Contextual Bible Study. Anglican Theological Review. 93(3), 431-49.
} 
invites participants first to "see" a passage in its original context, then to "judge" how the passage relates to the readers' own context(s), and finally to decide how she or he will "act" in response to new insights gained during the study. Each day focused on a different passage of scripture-Gen. 12:10-20 (Abram and Sarai's sojourn in Egypt); Luke 13:10-17 (Jesus' healing of the bent-over woman); and Rom. 2:1-11 (Paul's warning against judgment)which enabled participants to engage in the process of Contextual Bible Study using different genres of biblical literature. After the passage and relevant questions were provided to the whole conference, participants split up into break-out groups of eight or nine people for ninety minutes of study. Then, groups were asked to share their insights with the whole conference in plenary session.

As a participant in the conference, Prof. West was a resource to the three individuals who chose the scripture passages and accompanying questions as well as the other participants who undertook this approach to Bible study. He urged those selecting the passages to avoid biblical texts that had often been used in the debates over sexuality and, instead, suggested that more profound insights could be achieved if individuals were allowed to bring their own perspectives into the discussion of less familiar texts. The reader will notice that none of the chosen passages specifically addresses LGBT issues and only one of them (Gen. 12) deals with sexuality at all. Prof. West also encouraged the entire conference to use the "SeeJudge-Act" process to allow fresh, non-dominant perspectives from participants' home cultures to emerge through a rereading of the passages, an approach which he elsewhere describes as "adopting a 'pedagogical posture' that interrogates both the received scriptural tradition and local understandings of reality in a dialogical and collaborative manner." ${ }^{5}$ This manner of reading scripture was central to allowing the African and North American participants to find shared understandings of the texts.

Consider the biblical texts usually cited in discussions within Christian circles about homosexuality (e.g., Lev. 18:22 and 20:13; Rom. 1:26-27; 1 Cor. 6:9). For the LGBT community, these passages are "texts of terror," to borrow a term used by Phyllis Trible as the title of her 1984 work on feminist readings of historically misogynist biblical passages. ${ }^{6}$ The interpretation of these texts of terror in the debates over sexuality is fixed, and they are used to present interlocutors with an artificial choice: either condemn homosexual acts as unequivocally sinful (and, depending on one's reading of Lev. 20:13, worthy of death) or discount the authority of scripture for the modern Church. This is the point at which the clash of contradictory interpretations of Anglicanism reaches an impasse. Some in search of a theological argument that supports their progressive agenda would rather exorcise these "homophobic" verses from the discussion (and the canon) altogether. Others refuse to consider a theological proposition that is built upon the avoidance of relevant scriptural

\footnotetext{
${ }^{5}$ West, G. (2011). Do Two Walk Together? Walking with the Other through Contextual Bible Study. Anglican Theological Review. 93(3), 431-49

${ }^{6}$ Trible, Phyllis. (1984). Texts of Terror: Literary-Feminist Readings of Biblical Narratives. Minneapolis: Fortress Press.
} 
texts. Thus, the cycle of ineffective dialogue on sexuality and scripture is perpetuated by two sides of an argument that refuse to engage each other.

The "See-Judge-Act" method is used not to explain away these passages nor to elevate one of the other theological warrants as an alternative to scripture but to take scripture seriously by allowing it to speak today as it was originally written-as a contemporary message for a contemporary religious community. In other words, it values scripture primarily as contextual communication. Although the process begins with a discussion of the historical context into which the passage was first written by using questions like "What is this text about?" and "What do we know about each of the characters in the story?" participants quickly move beyond the ancient perspective by exploring connections with their own communities by asking questions like "What are the unspoken motives of the main characters?" and "How does this text speak to our respective contexts?" By freeing biblical passages from the contexts in which they were originally articulated, participants in Contextual Bible Study discover scripture's previously unvoiced implications for issues of human sexuality.

The vast majority of the canon is silent on issues of homosexuality and gender identity, yet the Bible is replete with stories of liberation, redemption, acceptance, and transformation. By choosing passages that had not previously been mined for their relevance to the discussion on sexuality and scripture, the presenters of the Contextual Bible Studies at the conference enabled participants to identify ways in which the Bible speaks to the inclusion of LGBT individuals in the life of the church. For one North American participant, the result was liberating. She acknowledged that in the past a cover-to-cover reading of the Bible almost drove her away from Christianity because of the dissonance she encountered between the original biblical context and that of her own life. This approach to Bible study-one that places equal emphasis on the contexts of the biblical authors and the contemporary inquirers-allowed her to recapture both the relevance and authority of scripture in her own faith. More generally, Contextual Bible Study enables participants to identify "texts of liberation" to accompany the well-known "texts of terror," making it possible to use scripture to balance the discussion. Recognizing the need to reground the Church-wide discussion on sexuality in the study of new scriptural texts, the North Americans at the conference named the development of a theological resource that explores sets of passages conducive to this approach as an important next step emanating from this gathering.

\section{Texts of liberation: an example}

A summary of the study of Luke 13:10-17 undertaken at the conference will help elucidate the ways in which the Contextual Bible Study model allows participants of radically different contexts to use scripture to find shared understanding. After splitting up into small groups, the study begins with a reading of the passage (Luke 13:10-17, ESV):

Now [Jesus] was teaching in one of the synagogues on the Sabbath. And behold, there was a woman who had had a disabling spirit for eighteen years. She was bent 
over and could not fully straighten herself. When Jesus saw her, he called her over and said to her, "Woman, you are freed from your disability." And he laid his hands on her, and immediately she was made straight, and she glorified God. But the ruler of the synagogue, indignant because Jesus had healed on the Sabbath, said to the people, "There are six days in which work ought to be done. Come on those days and be healed, and not on the Sabbath day." Then the Lord answered him, "You hypocrites! Does not each of you on the Sabbath untie his ox or his donkey from the manger and lead it away to water it? And ought not this woman, a daughter of Abraham whom Satan bound for eighteen years, be loosed from this bond on the Sabbath day?" As he said these things, all his adversaries were put to shame, and all the people rejoiced at all the glorious things that were done by him.

After a few moments of silence, the first question is asked by the facilitator: 1) What is this text about? Although startlingly simple, the question elicits responses of surprising complexity. Is the text about a healing? Is it about rules governing the Sabbath? Is the focus on Jesus' confrontation of the personified "spirit of disability" or on his confrontation with the ruler of the synagogue? Everyone is given the opportunity to identify what he or she feels the text is about. The second question follows as soon as the conversation from the first begins to ebb: 2) Who are the main characters, and what do we know about them? This allows participants to think more specifically about the characters in the story and relationships between them. It also encourages them to consider what those relationships would have meant to a first-century reader. These first two questions are the "See" portion of the model.

The "Judge" portion of the study begins with the next question: 3) What is the motive behind each of the characters' actions and words? The biblical text itself does not address this subject. The readers must use the text (and other passages in Luke and elsewhere in the Bible) and their own knowledge of that culture to infer the characters' motives. As the conversation continues, the focus is steadily shifting away from the original context and moving toward that of the participants. As the fourth question is asked, the process of integrating the multiple contexts is nearly complete: 4) What might the "disabling spirit" tell us about the woman? About the ruler of the synagogue? About the community? This is a pointed question, designed to help the participants name the underlying forces of oppression that are implicit in the passage. The responses of those taking part reveal the contexts and cultures from which they come. Is the ruler of the synagogue holding down the woman and other members of the community through his oppressive application of the requirements of faith? Is the community itself to blame for the woman's hunched-over posture, having ostracized her to the point at which their disdain becomes physically manifest in the object of their derision? The fifth question represents a completion of the shift in contexts: 5) If you were to tell the untold story of the woman in this passage, what story would you tell? Now, the participant is asked to supply a background to the biblical narrative by pulling from his or her own experiences and imagination, suggesting that one's 
own culture is as important as that into which the original story was communicated-the lynchpin for enabling those of different contexts to use the passage to develop a shared understanding.

Questions six and seven provide the "Act" step in the process: 6) What untold stories in your context does this passage remind you of? and 7) In what ways is God calling you to act as Jesus did? The first in this pair encourages participants to name who in their own contexts would take the place of the characters in the story. In other words, within their own communities, to whom would Jesus' healing be aimed? Is it the physically or mentally disabled? Is it the poor or the uneducated? Is it those who are marginalized because of their sexual orientation or gender identity? And also who is standing in the way of that healing? Is it the doctrine and discipline of the religious community? Is it the clergy who reinforce the rules of the faith? Is it the dominant community who embraces the status quo? The final question follows up where the sixth leaves off. Once one has named the object of oppression in his or her own context, how will that person respond as Jesus did-as a source of healing?

By lifting the story from its original setting and bringing it vibrantly into the contemporary context, one is able to hear this passage as more than just a story of healing from long ago. It becomes what it was to the original hearers: a story of dramatic liberation-literally an unbinding - that has direct implications for today's world. When individuals of substantially different hermeneutical contexts are all asking the same questions-"Who is bent-over under the weight of society's oppression?" and "How am I contributing to that oppression?" - scripture becomes central to the discussion in a way that is no longer controlled by society's dominant forces. The "texts of terror" no longer control the discussion because the "texts of liberation," which are far more numerous and central to the overarching themes of the Bible, are given their right place in the conversation. Thus, those who have previously avoided the use of scripture in the discussion of sexuality because of the terror that a few passages provide are able to engage those for whom scripture is the primary or even only warrant for a theological argument about the role of LGBT individuals in the life of the church.

\section{From intransigent debates to unanswered questions}

In recent years, the debates taking place within the Church over issues of sexuality have been relatively static because they have focused largely on those texts of terror. That is not to say that there has been no shift in the prevailing attitudes within various denominations or individual provinces of the Anglican Communion. For thirty years the Episcopal Church (USA) has taken significant steps toward the full inclusion of LGBT individuals in all aspects of church life, starting with a 1976 resolution (A069) declaring that "homosexual persons are children of God," continuing in 2003 with the consent to the election of V. Gene Robinson as Bishop of New Hampshire, and culminating most recently through its approval of a trial 
liturgy for the blessing of same-sex unions in 2012. ${ }^{7}$ Similarly, in 2012 after the Bishops in the House of Lords had initially rejected the British Government's bill to legalize same-sex marriage as theologically untenable as well as "unlikely to prove legally...[or] politically sustainable," the Convenor of the Lords Spiritual, the Bishop of Leicester, modified that position, stating, "Both Houses of Parliament have now expressed a clear view by large majorities...[so it] is now the duty and responsibility of the Bishops...to join with other Members in the task of considering how this legislation can be put into better shape." ${ }^{8}$

Still, though, those developments represent shifts in accepted practice, sometimes referred to "church discipline," rather than more substantial developments in understood theology or "church doctrine." In other words, the theological underpinnings beneath those changes in practice have not matured at all. Instead, those disciplinary changes are merely the product of a change in the majority position of Church leaders, which has shifted to reflect a similar and unrelenting change in secular culture-one firmly in favour of full inclusion. As a result, the Church remains divided between a shrinking but stalwart group that holds fast to traditional arguments about sexuality and a growing and passionate contingent that continues to articulate the same progressive arguments for inclusion. For the sake of the future of the Church, which depends upon those two parties coming to a consensus about each other's role in the Church, those stale, too-often rehashed debates must give way to fresh approaches to familiar issues.

In large part, the arguments for and against the acceptance of non-celibate homosexuals in the life and ministry of the Church have centered on the interpretation of biblical texts that prohibit physical intercourse between men (e.g., Lev. 20:13 and Rom. 1:26-27). Traditionally, the Church has looked at these texts as a clear prohibition not only of male homosexual intercourse but also on all male-male and female-female relationships that are analogous to heterosexual marriage. Despite the obvious physical differences associated with same-sex female relationships and the clear albeit less explicit potential differences in other manifestations of male-male intimacy, very little has been done specifically to address the Church's interpretation of relationships that fall outside the scope of "a man [lying] with a male as with a woman." ${ }^{\prime \prime}$ Rather than lining up on opposite sides of the debate over the relevance of a passage from the Holiness Code for the contemporary Church, theologians and other Church leaders should take direction from the secular world and invite expanded

\footnotetext{
${ }^{7}$ Kaleem, J. Episcopal Church Approves Gay Couples' Same-Sex Blessings. (2012, July 10). Huffington Post. Retrieved January 3, 2014, from http://www.huffingtonpost.com/2012/07/10/episcopal-church-gay-couplessame-sex-blessings_n_1663291.html; Standing Commission on Liturgy and Music. (2012). I will bless you, and you will be a blessing: Resources for blessing same-gender relationships. In G. Straub (Ed.), Report to the $77^{\text {th }}$ General Convention otherwise known as the blue book. (pp. 184-281). New York: The Office of the General Convention of the Episcopal Church.

${ }^{8}$ Church of England. A response to the Government Equalities Office Consultation - "Equal Civil Marriage"- from the Church of England. (June 2012). Retrieved January 3, 2014, from

http://www.churchofengland.org/media/1475149/s-s\%20marriage.pdf; Church of England. Same-sex marriage. Retrieved January 3, 2014, from http://www.churchofengland.org/our-views/marriage,-family-and-sexualityissues/same-sex-marriage.aspx.

${ }^{9}$ Lev. 20:13 (ESV).
} 
discussion on the potential holiness of lifelong same-sex relationships. This is an opportunity for using the Contextual Bible Study model to revisit the role of scripture in these issues.

In a substantial way, these issues were undertaken by the Standing Commission of Liturgy and Music of the Episcopal Church (USA) in its 2012 report "I Will Bless You, and You Will Be a Blessing." The previous General Convention in 2009 had called for the Standing Commission to "'collect and develop theological and liturgical resources' for the blessing of same-gender relationships." Although the most prominent part of their response was the liturgy itself, it also contained expansive work in missiology, the theology of blessing, and the nature of covenanted relationships. Specifically in that last area, the commission focused on the sacramental and eschatological natures of same-sex relationships. By exploring ways in which they "become outward and visible signs of God's grace" (i.e., their sacramental nature) and how they "evoke our desire for union with God" (i.e., their eschatological nature), the report offers new and far-reaching comparisons between heterosexual marriage, homosexual partnerships, and the paschal mystery as "the very root and source of life in the couple's relationship." ${ }^{10}$ In this way, the Standing Commission has looked to expressions of faithfulness in the secular world to inform the theological conversation about the potential holiness of committed same-sex relationships. Continued work in this area is important for the wider Church as it wrestles with the place of LGBT individuals in its sacramental life.

The General Convention, by approving Resolution A049, has commended the Standing Commission's report "for study and use" within the Episcopal Church and has also instructed the Standing Commission to "develop an open process to review" responses to its work from around the Anglican Communion in recognition of the need for increased and wider dialogue on these issues of doctrine. ${ }^{11}$ Also, in resolution A050, the 2012 General Convention called for the creation of a task force on the study of marriage-a logical next step in the theological conversation about the holiness of same-sex relationships. Despite this work, however, the role of scripture in these newer subjects of conversation remains undeveloped. Although the persistently progressive movement of the Episcopal Church already suggests a particular outcome of these next steps, the theological discussion behind them remains to be seen. How will the Church articulate a sacramental understanding of non-gender-specific marriage? Is the lifelong monogamous covenant of two men or two women equivalent to that of opposite-gender partners both ethically and eschatologically? Is the Christian concept of marriage more profoundly injured by increasing rates of malefemale cohabitation or by increasing rates of same-sex partnerships? These are the issues that the Church should focus on rather than simply rehashing the well-worn and immovable

\footnotetext{
${ }^{10}$ Standing Commission on Liturgy and Music. (2012). I will bless you, and you will be a blessing: Resources for blessing same-gender relationships. In G. Straub (Ed.), Report to the $77^{\text {th }}$ General Convention otherwise known as the blue book. (pp. 184-281). New York: The Office of the General Convention of the Episcopal Church. ${ }^{11}$ Standing Commission on Liturgy and Music. (2012). Resolution A049: Authorize Liturgical Resources for Blessing Same-Gender Relationships. The Office of the General Convention of the Episcopal Church. Retrieved December 29, 2013, from http://www.generalconvention.org/resolutions/download/115-1342125335.
} 
arguments that are based on only a few scripture passages. The only way that the Church can engage in a productive conversation about them is by finding a way to bring the wider story of scripture into the discussion through the use a method like the Contextual Bible Study model, which can bridge the divide between those of substantially different theological perspectives.

\section{Conclusion}

On the issue of human sexuality, no one seems to doubt that the Church is in a time of considerable transition. Too often, however, the conversation on sexuality is characterized by two sides that espouse inflexible and inconsonant positions. Usually, that conflict is centred on the reading of scripture. Unless that pattern of intransigence changes, the future of the Church can only be one of schism. The approach to scripture known as Contextual Bible Study offers an opportunity for individuals of different (even opposing) hermeneutical backgrounds to read and interpret passages of scripture and discover agreement even on issues of human sexuality. By learning this approach to taking scripture seriously, both sides of the debate over the inclusion of LGBT individuals in the life of the Church can find ways to discuss issues that have not yet been decided.

The Revd Evan D. Garner serves as the Rector of St. John's Episcopal Church in Decatur, Alabama (USA). After training for ministry at Ridley Hall Theological College in Cambridge, he was ordained and served in a parish in Montgomery, Alabama. He was a deputy to the Episcopal Church's General Convention in 2012 and currently serves as a member of its Standing Commission for Lifelong Christian Formation and Education. He and his wife Elizabeth have three young children. 